\title{
ERC1 wt Allele
}

National Cancer Institute

\section{Source}

National Cancer Institute. ERC1 wt Allele. NCI Thesaurus. Code C97501.

Human ERC1 wild-type allele is located in the vicinity of 12 p13.3 and is approximately 505

$\mathrm{kb}$ in length. This allele, which encodes ELKS/Rab6-interacting/CAST family member 1

protein, is involved in the modulation of signaling. Both mutation of the gene and a

chromosomal translocation $\mathrm{t}(10 ; 12)(\mathrm{q} 11 ; \mathrm{p} 13)$ of this gene and the RET gene are associated with thyroid papillary carcinoma. 